$\xi=$

\title{
Characterization of best naringinase producing fungus isolated from the citrus fruits
}

\author{
Keerthini Srikantha $^{1}$, Ranganathan Kapilan ${ }^{2} *$, Vasantharuba Seevaratnam ${ }^{1}$ \\ ${ }^{1}$ Department of Agricultural Chemistry, Faculty of Agriculture, University of Jaffna, Sri Lanka \\ ${ }^{2}$ Department of Botany, Faculty of Science, University of Jaffna, Sri Lanka \\ *Corresponding authorE-mail:ranganat@ualberta.ca
}

\begin{abstract}
Naringinase enzyme has potential application in food and pharmaceutical industry. Naringin and limonin are principle bitter components in the citrus fruit. The microorganisms that associate with citrus fruit may have the ability to degrade the naringin by extracellular naringinase enzymes that are produced by microorganisms. The objective of the study is to isolate naringinase producing fungus from the citrus fruit to debitter the citrus juice and to characeterize the fungus. Citrus fruits were allowed to spoil under the air and soil and the lesion was used to streak on fresh PDA plates. Out of the eight strains isolated from citrus fruits, five were positive for naringinase enzyme. When all the naringinase producing fungi were subjected to liquid fermentation medium for eight days at room temperature at 200 $\mathrm{rpm}$ and the crude enzyme was tested for naringinase enzyme at $\mathrm{pH} 5$ and $50{ }^{\circ} \mathrm{C}$ for 10 minutes, one strain showed the best naringenase activity $(1.92 \mu \mathrm{mol} / \mathrm{ml} / \mathrm{min})$. This strain was identified as Aspergillus flavus based on the macroscopic, microscopic and biochemical tests. The culture conditions were optimized to increase the naringinase production via solid state fermentation system using paddy husk as the support. Though naringinase activity of Aspergillus flavus has started on the 2nd day, the highest activity (449.58 $\left.\mathrm{Ug}^{-1} \mathrm{Dry} \mathrm{Matter}\right)$ was obtained on the 8th day. Thereafter the naringinase activity has started to decline. Solid state fermentation using paddy husk as support could be used for large scale naringinase enzyme production.
\end{abstract}

Keywords: Aspergillus flavus; Citrus Fruit; Naringinase; Paddy Husk; Solid State Fermentation.

\section{Introduction}

Citrus fruit juice has potential consumer demand due to its nutritional value and taste. Naringin is one of the bitter component that is found in citrus fruits. When extraction of juice from the citrus fruits is done, naringin will impart the bitterness taste to the juice. Therefore, elimination of naringin or alteration of naringin into bitter less or bitter free component is important to achieve the consumer acceptance of citrus juice. Other than the above, citrus peel is considered as waste in the food industry, which has naringin as a principle component. If a proper technology is employed, Citrus pulp with peel have potential application in food and pharmaceutical industry, namely debittering of citrus juice, production of citrus peel concentrate, production of antibiotics, anti-inflammatory and antiviral component from citrus peel. Among the several methods employed, enzymatic degradation is found to be a cost effective method. Naringinase is an enzyme complex, which is appropriate for above targets. Naringinase expresses activity on $\alpha$-L-rhamnosidase and $\beta$-D-glucosidase ( $\mathrm{Ri}$ bero, 2011). The end products are glucose and naringenin. Naringinase has been isolated from plant- cerery seeds (Hall, 1938), grape fruit leaves (Thomas et al. 1958), Rhamnus Daurica (Suzuki, 1962) and Fagopyrum esculentum (Bourbouze et al. 1976) and Gastropod (Kurosawa et al. 1973) and pig liver (Qian et al., 2005) and Fungus- Penicillium decumbens (Mamma et al, 2004), Aspergillus niger MTCC1344 (puri et al, 2005), Aspergillus niger (BCC 25166) (Thammawat et al., 2008), Aspergillus kawachii (Koseki et al. 2008), Penicillium ulaiense (Rajal et al., 2009), Aspergillus sojae (Chang et al., 2011), etc. and Yeast-Pichiaangusta (Yanai and Sato, 2000), Cryptococcus laurentii (Li et al., 2011) and Bacteria- Bacillus sp.GL 1 (Hashimoto et al., 2003), Lactobacillus plantarum (Avila et al., 2009), Lactobacillus acidophillus (Beekwilder et al., 2009), Staphylococcus xylosus (Puri et al., 2011)etc. (Puri, 2012) Serratia spp (Pavithra et al., 2012), Micrococcus sp (Amena et al., 2014). Previously naringinase producing organisms were isolated from different sources. Out of 150 strains isolated from corncob, palmyrah fruit fibre, opened naringin plate, sugarcane, house garbage, beetroot and neem fruit, fungal strain that was isolated from beetroot has highest activity (Navarantnam et al., 2003). Other than that naringinase producing organisms were isolated from soil (Thammawat et al., 2008), 'Guanxipomelo'flesh (Chen et al., 2010), and Soil culture of Namakkal Poultry House (Radhakrishnan et al., 2013). The reasons for selection of citrus for this work are naringin is the major component in all parts of citrus fruit (Kefford, 1959).

Therefore, the microorganism that associates with citrus fruit may have the potential for hydrolyze the naringin and impart naringinase production, citrus is easily accessible and cheapest fruit during season in Sri Lanka, and citrus peel can be used as substrate for naringinase production instead of purchasing naringin, which may favorable for fungi that were isolated from citrus. With in citrus family, only few spp are utilized. Other spp are in underutilized condition, it may be due to their bitterness. So it can be utilized during naringenase production, further it can be utilized for industrial product formulation with cheapest cost.

The objective of the study was to isolate naringinase producing fungi from bitter citrus fruit and peels, to characterize the fungi and to compare the enzyme production both in the liquid and solid state fermentation systems. 


\section{Materials and methods}

\subsection{Chemicals}

Naringin was obtained from Sigma, St. Louis, USA. All other reagents were in analytical grade. The chemicals used were from standard sources.

\subsection{Sample collection}

Fungi were isolated from the citrus fruits, which were allowed to spoil in air and soil. For the isolation of possible naringin utilization fungi from air, the citrus fruit peels were exposed to air on $0.2 \%$ naringin added agar plates. For the isolation naringin utilizing fungi from soil, the whole citrus fruit and citrus peels were buried in 5 different location soil samples (near the citrus tree, near the irrigation channel, garden, farm and less fertility soil) Decayed samples were collected after one and two weeks. In addition to spoiled citrus pieces that were collected from soil, the soil samples found around the place where decaying of Citrus pieces were done, were also collected in sterilized bags.

\subsection{Isolation of strain}

For the isolation of naringin associated fungus, Decaying citrus pieces were directly transferred aseptically onto the naringin agar plate that containnaringin- $0.2 \%$, yeast extract $-0.1 \%$, glucose- $0.5 \%$ mineral solution- $10 \mathrm{ml} / 100 \mathrm{ml}$ medium (mineral solution $\left.\mathrm{ZnSO}_{4} .7 \mathrm{H}_{2} \mathrm{O}-0.07 \%, \mathrm{CuSO}_{4} .5 \mathrm{H}_{2} \mathrm{O}-0.07 \%, \mathrm{FeSO}_{4} .7 \mathrm{H}_{2} \mathrm{O}-0.07 \%\right)$ (Navarantnam et al., 2003). For the isolation of fungi from collected soil samples, soil plate method and soil dilution plate method were employed (Warcup, 1950, Waksman, 1922) After 3 days, fungi were distinguished according to the macroscopic characteristic features. Spores of different morphological fungi were streaked on separate PDA plate under aseptic conditions. This procedure was continued until a pure culture was obtained.

\subsection{Primary screening (qualitative assay)}

The pure culture was cultured on Naringin PDA plates for growth. Naringinase producing strains were screened by $1 \% \mathrm{Fecl}_{3}$. Colour changes in media were observed after 7 days. Plates that contained fungal strains that appeared reddish brown colour, were selected and cultured on PDA slant for further analysis (Radhakrishnan et al., 2013).

\subsection{Secondary screening (quantitative assay)}

Secondary screening was done by performing naringinase enzyme activity assay to the supernatant collected from the liquid media that were allowed to ferment each primary screened fungi.

\subsubsection{Preparation of inoculums for fermentation}

6 days old culture was used to prepare the inoculums for the fermentation. Spores were separated from the PDA slant by sterilized $0.85 \% \mathrm{Nacl}$ and inoculums size was adjusted to $1 * 10^{8}$ by dilution with the help of heamocytometer.

\subsubsection{Fermentation}

Liquid state fermentation was carried out to fungi strain; those were showed the positive result for the primary screening. Solid state fermentation was carried out to best naringinase producing fungi that was screened by naringenase activity assay.

\subsection{2. a Enzyme production on liquid state fermentation}

For the production of naringinase, $1 \mathrm{ml}$ of $1 * 10^{8}, 6$ days old spores were added to $100 \mathrm{ml}$ fermentation medium that contain $(\%)$ naringin-0.2, glucose-0.2, peptone-0.7, $\mathrm{MgSO}_{4} .7 \mathrm{H}_{2} \mathrm{O}-0.01$,
$\mathrm{KH}_{2} \mathrm{PO}_{4}-0.05$, mineral solution- $10 \mathrm{ml} / 100 \mathrm{ml}$ medium (mineral solution $-\mathrm{ZnSO}_{4} .7 \mathrm{H}_{2} \mathrm{O}-0.07 \%, \quad \mathrm{CuSO}_{4} 5 \mathrm{H}_{2} \mathrm{O}-0.07 \%$, $\left.\mathrm{FeSO}_{4} \cdot 7 \mathrm{H}_{2} \mathrm{O}-0.07 \%\right)$ and initial $\mathrm{pH}$ was adjusted to 6 (Navarantnam et al.,2003), and that was previously sterilized at $121^{\circ} \mathrm{C}, 15 \mathrm{psi}$ for $15 \mathrm{~min}$. Then it was allowed for 8 days at room temperature and $200 \mathrm{rpm}$. Three replicates were performed for each fungi strain in separate $500 \mathrm{ml}$ conical flask.

\subsection{2. b Enzyme production on solid state fermentation}

Media composition and $\mathrm{pH}$ is same as liquid state fermentation. In addition to liquid medium $20 \%$ of paddy husk was added, that was previously cleaned and dried under sun light. Media and paddy husk were sterilized at $121^{\circ} \mathrm{C}, 15$ psi for 15 min separately. After that paddy husk were transferred aseptically. Fermentation medium was allowed for 8 days at room temperature in dark incubator. This only done to best strain and three replicates is performed.

Fermented liquid medium was taken aseptically for naringinase assay.

\subsubsection{Naringinaseassay}

The fermented liquid medium was centrifuged at $10000 \mathrm{rpm}$ for 20 minutes. From that $0.25 \mathrm{ml}$ supernatant was taken and allowed for pre incubation $\left(40^{\circ} \mathrm{C}, 3\right.$ minutes). After that pre incubated naringin solution, which prepared with the help of $0.1 \mathrm{M}$ citric acid and $0.2 \mathrm{M} \mathrm{NaH}_{2} \mathrm{PO}_{4}(\mathrm{pH}-4.5)$ was mixed with pre incubated supernatant and enzyme and supernatant mixture was allowed to react at $50^{\circ} \mathrm{C}$ for 10 minutes. Then reaction was terminated by addition of DNS reagent. After that this was stirred well and boiled for 5 minutes. Then this was allowed to cool. Finally $5 \mathrm{ml}$ of distilled water was added and stirred well. For the blank, $0.5 \mathrm{ml}$ DNS reagent was added to $0.25 \mathrm{ml}$ naringin substrate and this mixture was stirred well $.0 .25 \mathrm{ml}$ of supernatant was added to this and allowed to boil for 5 minutes. Then this was allowed to cool. Finally $5 \mathrm{ml}$ of distilled water was added and stirred well. The absorbance of test was measured by spectrometer at $550 \mathrm{~nm}$ with help of blank.

Naringinase activity was calculated with the help of glucose standard curve. The method of Miller (1959) was used to prepare the standard curve.

$$
\begin{aligned}
& \text { Naringinase activity }=\frac{1}{\begin{array}{c}
\text { Standard reading } \\
\text { (OD of } 0.5 \mathrm{mg} \text { glucose })
\end{array}} \times \text { OD of test } \\
& \mathrm{x} \frac{1}{\text { Volume of supernatant }} \times \frac{1}{\text { Time }} \times \frac{1000}{180} \\
& \text { Naringinase activity }=\frac{\text { (Activity } \mathrm{x} \text { Total volume }) / 2}{(1-\text { moisture content })}
\end{aligned}
$$

Second equation was represented naringenase activity per gram of dry weight of substrate. Moisture content was determined to squeeze paddy husk, which was kept in oven at $80^{\circ} \mathrm{C}$ until constant weight. One $\mu \mathrm{mol} / \mathrm{ml} / \mathrm{min}$ was defined as amount of enzyme that could hydrolyze the $1 \mu \mathrm{mol}$ of naringin per $\mathrm{ml}$ and minute at assay conditions (Thammawet et al., 2008).

\subsection{Identification of best naringinase producing fungal strain}

The selected strain was identified using the macroscopic, microscopic and biochemical features. For macroscopic observation spore was inoculated to PDA slant. Every day their growth pattern, colony colour and sporulation were observed. Additionally few selected media was used; namely CzapekDox agar, Malt Extract Agar with two replicates. This selected media were kept at $25^{\circ} \mathrm{C}$ up to seven days, after inoculation of spore. Every day colour of the colony was observed and after 7 days, the diameter of colony was measured by Fisher scientific traceable digital caliper and conidia head and conidia were observed through the microscope with the help of staining with cotton blue dye. Diameter of 
conidia was measured through the stage microscope. For the biochemical identification, spore was inoculated on the two Coconut cream agar plates and kept up to 7 days at $25^{\circ} \mathrm{C}$. After seven days, the culture plate was observed through UV light.

\section{Results and discussion}

\subsection{Isolation of strain}

Eight fungal strains were isolated from the citrus and they were labeled as $\mathrm{FIC}_{1}, \mathrm{FIC}_{2}, \mathrm{FIC}_{3}, \mathrm{FIC}_{4}, \mathrm{FIC}_{5}, \mathrm{FIC}_{6}, \mathrm{FIC}_{7}, \mathrm{FIC}_{8}$ (FICFungus Isolated from Citrus). $\mathrm{FIC}_{1}, \mathrm{FIC}_{2}, \mathrm{FIC}_{4}$ and $\mathrm{FIC}_{5}$ were isolated from the citrus fruits that were allowed to decay in the natural atmosphere. $\mathrm{FIC}_{1}, \mathrm{FIC}_{7}$ and $\mathrm{FIC}_{8}$ were isolated from the buried citrus fruits and peels. Strains $\mathrm{FIC}_{1}, \mathrm{FIC}_{6}$ and $\mathrm{FIC}_{8}$ were isolated from the soil that was collected around the buried citrus fruits.

\subsection{Primary screening}

Qualitative assay was conducted as primary screening. For that Naringin PDA plates with $1 \% \mathrm{Fecl}_{3}$ were used. If the fungi strain produced the naringenase enzyme, then it could have hydrolyzed the naringin found in the plate. The end product of above reaction would be naringenin. Naringenin reacts with $\mathrm{Fecl}_{3}$ and gives a reddish brown colour (Radhakrishnan et al., 2013). Therefore the strains that gave reddish brown colour appearence were considered as naringinase producing strains (Figure 1). In the primary screening, there were five fungi strains showed possitive responses, and they were named as $\mathrm{FIC}_{1}, \mathrm{FIC}_{2}, \mathrm{FIC}_{4}, \mathrm{FIC}_{7}$ and $\mathrm{FIC}_{8}$.

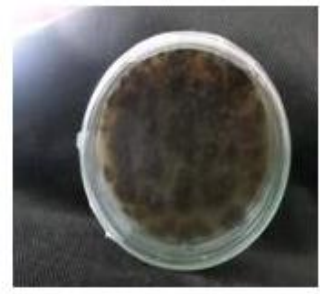

FIC1

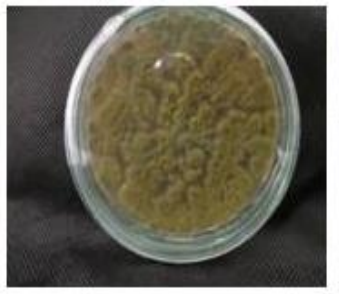

FIC 2

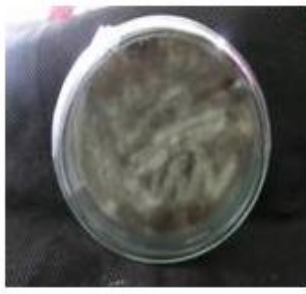

FIC 4

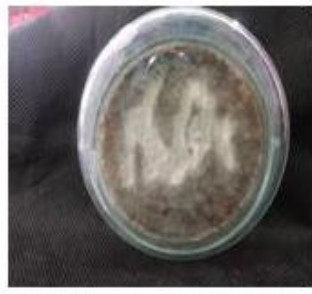

FIC 7

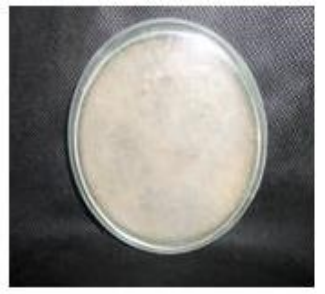

FIC8

Fig. 1:Positive Results Shown by the Fungal Strains to Primary Screening.

\subsection{Secondary screening}

Table 1:NaringinaseActivity of the Fungal Strains on Liquid Fermentation Medium after 8 Days

\begin{tabular}{lll}
\hline No & Fungus & Naringinase activity $(\mu \mathrm{mol} / \mathrm{ml} / \mathrm{min})$ \\
\hline 1 & FIC 1 & 1.8898 \\
2 & FIC 2 & 1.9159 \\
3 & FIC 4 & 1.8963 \\
4 & FIC 7 & 1.8246 \\
5 & FIC 8 & 1.2346 \\
\hline
\end{tabular}

Naringinase has the $\alpha$-Lrhamnosidase activities and $\beta$-Dglucosidase activities. Therefore, naringinase can hydrolysenaringin into prunin, rhamnose, glucose and naringenin. In the naringinase assay, the glucose concentration was measured (glucosidase activity) with the help of DNS acid. Aldehyde group of glucose molecule reduces DNS acid to orange coloured 3-amino5-nitrosalicylic acid on boiling. Intensity of the colour is proportional to concentration of glucose in solution (Miller, 1959). Naringinase enzyme activity was increased with the increasing glucose concentration. Out of the five strains tested, the strain that showed highest activity $\left(1.9159 \mu \mathrm{mol} / \mathrm{ml} / \mathrm{min}\right.$ on the $4^{\text {th }}$ day Table 1) in the liquid fermentation media was selected. This strain was characterized and used in the solid state fermentation system using cheap, easily available agricultural waste paddy husk as support.

Naringinase production of the selected strain was promoted in solid state fermentation when paddy husk was used as a support when compared to liquid state fermentation $(3.468 \mu \mathrm{mol} / \mathrm{ml} / \mathrm{min})$. Highest naringenase activity (449.5842 U per gram of dry weight

of substrate - Table 2) was recorded on the $8^{\text {th }}$ day with the selected strain in the solid state fermentation system with paddy husk as support. Therefore it may be considered as paddy husk may induce the naringenase production by promotion of aeration and increasing the surface area. When comparing with liquid fermentation, SSF is cost effective one that could be carried out with low cost agro wastes. It further facilitates the utilization of paddy husk which is an underutilized agro waste. Economical and environmental point of naringinase production, the solid state fermentation with paddy husk as support, is better than liquid state fermentation method.

Table 2:NaringinaseActivity of the Fungal Strain $\mathrm{FIC}_{2}$ after Eight Days of Fermentation in Solid State Fermentation System Using Paddy Husk as A Support

\begin{tabular}{ll}
\hline Replicates & $\begin{array}{l}\text { Naringinase activity } \\
\text { U/g of dry weight of substrate }\end{array}$ \\
\hline 1 & 447.1384 \\
2 & 449.5047 \\
3 & 452.1095 \\
Average activity & 449.5842 \\
\hline
\end{tabular}

\subsection{Identification of best naringenase producer (FIC2)}

$\mathrm{FIC}_{2}$ was identified as Aspergillus flavus with the help of macroscopic, microscopic and biochemical features.

\subsubsection{Macroscopic characters}

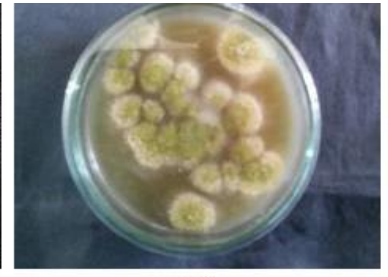

(c)

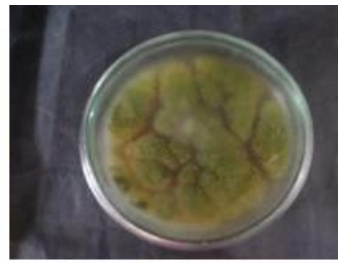

(d)

Fig. 2: (A) A.flavus in CZA, after 4 Days Incubation at $25^{\circ} \mathrm{c}$; (B) A.flavus in CZA, after 7 Days Incubation at $25^{\circ} \mathrm{c}$; (C) A.favus in MEA, after 4 Days Incubation at $25^{\circ} \mathrm{c}$; (D) A.flavus in MEA, after 7 Days Incubation at $25^{\circ} \mathrm{c}$. 
Colonies of the A.flavus strain on CZA (CzapekDox Agar) media were $44.96 \mathrm{~mm}$ in diameter after 7 days at $25^{\circ} \mathrm{C}$. Colony color on CZA showed variation in different strains from yellow to green, or darkgreen, reverse hyaline. Sclerotia of the fungi were white to wood brown. Exudates were transparent to red brown droplets in heavily sclerotial strain. Colonies on MEA (Malt Extract Agar) media were $57.5 \mathrm{~mm}$ in diameter after 7 days at $25^{\circ} \mathrm{C}$. Colony color on MEA was dark green to reverse hyaline. Initially the colonies on CZA and MEA were yellow in colour and with the time they become green colour.

\subsubsection{Microscopic characters}

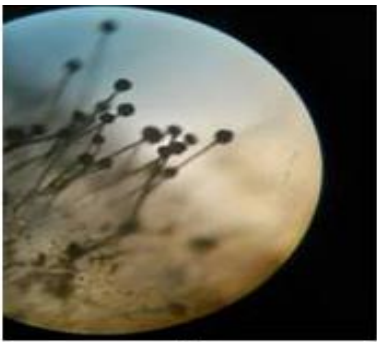

(a)

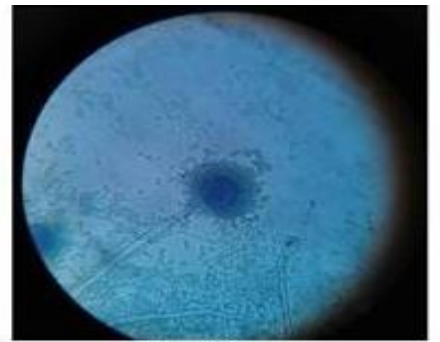

(b)

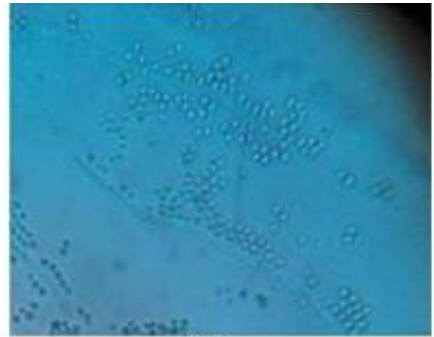

(c)

Fig. 3:Light Microscope Pictures of Aspergillus flavus (A) Condial head and Conidiophore at Low Power and (B) Condial head at High Power and (C) Condia at High Power.

Conidial heads of A.flavus were radiate, biseriate and $280 \mu \mathrm{m}$ in diameter. Conidia was subglobose-globose and $3 \mu$ in diameter. Conidiophore was uncolored and roughened, $0.9 \mathrm{~mm}$ long, $10 \mu$ width with $2 \mu \mathrm{m}$ thick wall. Vesicle was globose, $25 \mu \mathrm{m}$ in diameter. Metulae was $6 \mu \mathrm{m}$ long. Phialides were ampuliform. These features were observed for the selected fungus A.flavus after 7 days, when culture was grown on Malt Extract Agar medium.

\subsubsection{Biochemical features}

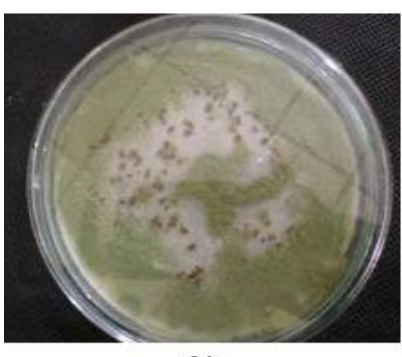

(a)

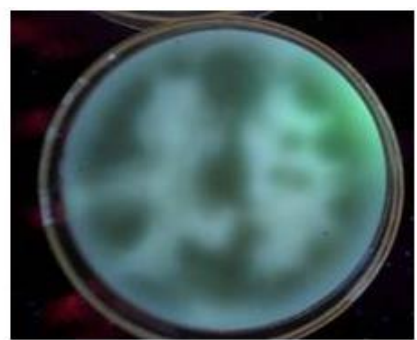

(b)
Fig. 4: (A) A.flavus in Coconut Flour Agar Plate with Brown Extrudes; (B) A.flavus in Coconut Flour Agar Plate under UV Light Shows Green Fluorescence.

Aspergillus flavus has the ability to produce alflatoxin in Coconut flour agar plate, it will result the green fluorescence under UV light (Venâncio et al., 2007).

The best naringinase enzyme producer was characterized and identified as Aspergillus flavus from morphological and biochemical test and identification keys. Although the organism has been previously isolated from the soil culture in the Namakkal Poultry House and proved its capacity to produce naringinase enzyme (Radhakrishnan et al., 2013). Aspergillus flavus MTCC-9606, which was isolated from decaying lemon fruit was proved as $\alpha$-LRhamnosidase producing strain(Yadav et al. 2011). While our work, we found Aspergillus flavus as best naringenase producing strain (especially $\beta$-D-glucosidase) among citrus associated fungi. Previously Aspergillus flavus was exploited to enhance naringinase activity by optimizes the fermentation medium (Radhakrishnan et al. 2012).

Naringinase production in solid state fermentation was previously documented from filamentous fungi namely; Aspergillus niger and Aspergillus niger HPD-2, where grape fruit rind was used as solid state (Ortiz-vázquez, et al., 2010). The activity was less than which we got from our experiment. The differences in the amount of naringinase production may vary due to media composition and type of substrate used as the solid medium.Grapefruit rind and mineral solution that contain $\mathrm{KH}_{2} \mathrm{PO}_{4}, \mathrm{NH}_{4} \mathrm{Cl}, \mathrm{MgSO}_{4} \cdot 7 \mathrm{H}_{2} \mathrm{O}$, and $\mathrm{FeCl}_{3}$ as media composition without any organic nitrogen source and additional carbon source were used in the enzyme production. Since the contents of the media may not be adequate there was a reduction in the enzyme production by Aspergillus foetidus. Effect of naringin and naringenin were investigated separately with $A s$ pergillus flavus on PDB medium and the activity of naringinase was tested. The results indicated that the increasing concentration of naringenin up to $0.08 \mathrm{mg} / \mathrm{L}$ increases the enzyme activity, but increasing naringin from $50 \mathrm{mg} / \mathrm{L}$ did not increase the naringenase activity. The activity at $0.08 \mathrm{mg} / \mathrm{L}$ was $1.160 \mathrm{U} / \mathrm{ml}$ (Radhakrishnan et al., 2012). This naringinase activity was considerably lower than what we got from Aspergillus flavus. The reason in the difference in the enzyme production may differ due to the noncondusive environment and less nutritive media for the enzyme production they used.

\section{Conclusion}

Fungi that associate with citrus fruits have the ability to produce naringinase enzyme and this is not appropriate for all fungi associations with citrus fruits. Among the isolated strains Aspergillus flavus is the best naringenase enzyme producer under solid state fermentation system using the cheap agro-waste paddy husk. Usage of underutilized citrus varieties could be considered for the production of naringinase enzyme to reduce bitterness in the industrial level applications.

\section{Acknowledgement}

Authors sincerely thank the University of Jaffna for awarding the Research Grant to Dr.S.Vasantharuba, Department of Agricultural Chemistry, in 2015. Technical support by Mr. P.T.J.Jashothan and timely assistance by Mr.A.Thananchayan, Departmnt of Botany are highly appreciable.

\section{References}

[1] Afza H, Shazad S, Nisa SQU. Morphological identification of aspergillus species from the soil of larkana district ( $\operatorname{sindh}$, pakistan ). Asian J Agri Biol. 2013, 1 (3):105-117.

[2] Avila M, Jaquet M, Moine D, Requena T, Palaez C, Arigoni F. Physiological and biochemical characterization of the two rhamnosidase of Lactobacillus plantarum. Microbiology. 2009, 155:2739 2749.http://dx.doi.org/10.1099/mic.0.027789-0.

[3] Beekwilder J, Marcozzi D, Vecchi S, deVos R, Janssen P, Francke C, Hall RD. Characterization of rhamnosidases from Lactobacillus plantarum and Lactobacillus acidophilus. App Environ Microbiol. 2009, 75:3447-3454.http://dx.doi.org/10.1128/AEM.02675-08. 
[4] Bourbouze R, Percheron F, Courtois JE. $\alpha$-L-rhamnosidase from Fagopyrum esculentum: purification and some properties. Eur J Biochem. 1976, 63:331-337.http://dx.doi.org/10.1111/j.14321033.1976.tb10234.x.

[5] Bram B, Solomons GL. Production of the Enzyme Naringinase by Aspergillus niger. Applied microbiology. 1965, 13 (6):842-845.

[6] Chang HY, Lee YB, Bae HA, Huh JY, Nam SH, Sohn HS, Lee HJ Lee SB. Purification and characterization of Aspergillus sojaenaringinase: the production of pruning exhibiting markedly enhanced solubility with in vitro inhibition of HMG-CoA reductase. Food Chem. 2011, 124:234 241.http://dx.doi.org/10.1016/j.foodchem.2010.06.024.

[7] Chen D, Niu T, Cai H. Optimizing culture medium for debittering constitutive enzyme naringinase production by Aspergillus oryzae. African Journal of Biotechnology. 2010, 9 (31):4970-4978.

[8] Hall D. A new enzyme of the glycosidase type. Chem Ind.1938, 57:473.http://dx.doi.org/10.1038/142150a0.

[9] Hashimoto W, Miyake O, Nankai H, Murata K. Molecular identification of a $\alpha$-L-rhamnosidase from Bacillus sp. strain GL1 as an enzyme involved in complete metabolism of gellan. Arch Biochem Biophy. 2003， 415:235-244.http://dx.doi.org/10.1016/S00039861(03)00231-5.

[10] Kefford JF. The chemical constituents of citrus fruits. Advances in food research. 1960,9:285-372.http://dx.doi.org/10.1016/S00652628(08)60278-5.

[11] Koseki T, Mese Y, Nishibori N, Masaki K, Fuhii T, Handa T, Yamane Y, Shiono Y, Murayama T, iefuji H. Characterization of an $\alpha$ L-rhamnosidase from Aspergillus kawachii. ApplMicrobiolBiotechnol. 2008, 80:1007-1013.http://dx.doi.org/10.1007/s00253008-1599-7.

[12] Li L, Ni H, Xiao A, Cai H. Characterization of Cryptococcus sp. jmudeb008 and regulation of naringinase activity by glucose. Wei Sheng Wu XueBao. 2010, 50:1202-1207.

[13] Mamma D, Kalogeris E, Kekos D, Macris BJ, Christakopoulus P. Biochemical characterization of the multi-enzyme system produced by $P$. decumbens grown on ruitn. Food Biotechnol. 2004, 18:118.http://dx.doi.org/10.1081/FBT-120030382.

[14] Mcclenny N. Laboratory detection and identification of Aspergillus species by microscopic observation and culture : the traditional approach. Medical Mycology Supplement. 2005, 43:125128.http://dx.doi.org/10.1080/13693780500052222.

[15] Miller GL. Use of Dinitrosalicylic acid reagent for determination of reducing sugar. Analytical Chemistry. 1959, 31 (3): 426428.http://dx.doi.org/10.1021/ac60147a030.

[16] Navaratnam P, Ketheeswary N, Senthuran A, Arasaratnam V. Preliminary studies on the isolation of naringinase producing fungus. Jaffna Science Association. 2003,11:10.

[17] Ortiz-Vázquez E, Mendoza-Cal A, Cuevas-Glory L, Lizama-Uc G. Naringinase production from filamentous fungi using grapefruit rind in solid state fermentation. African Journal of Microbiology Research. 2010, 4 (19):1964-1969.

[18] Pavithra M, Belur PD, Saidutt MB. Production of Naringinase by a new soil isolate of Serratia Sp. Effect of different carbon and nitrogen sources. Research Journal of Biotechnology. 2012,7(4):208211.

[19] Puri M, Banerjee A, Banerjee UC. Optimization of process parameters for the production of naringinase by Aspergillus niger MTCC 1344. Process Biochemistry. 2005,40:195-201. http://dx.doi.org/10.1016/j.procbio.2003.12.009.

[20] Puri M, Kaur A, Barrow CJ, Singh RS. Citrus peel influences the production of an extracellular naringinase by Staphylococcus $x y$ losus MAK 2. ApplMicrobiolBiotechnol. 2011, 89:715722.http://dx.doi.org/10.1007/s00253-010-2897-4.

[21] Puri M. Updates on naringinase: Structural and biotechnological aspects. Appl Microbiol Biotechnol. 2012, 93:4060.http://dx.doi.org/10.1007/s00253-011-3679-3.

[22] Qian S, Yu H, Zhang C, Lu M, Wang H, Jin F. Purification and characterization of dioscin- $\alpha$-L-rhamnosidase from pig liver. Chem Pharm Bull. 2005, 53: 911-914. http://dx.doi.org/10.1248/cpb.53.911

[23] Radhakrishnan I, Sampath S. Optimization of medium composition for improving naringinase activity using response surface methodology. International Journal of Bio-Technology and Research (IJBTR). 2012, 2 (3):29-36.

[24] Radhakrishnan I, Sampath S, Kumar S. Isolation and characterization of enzyme naringinase from Aspergillus flavus. International Journal of Advanced Biotechnology and Research. 2013,4(2):208212.

[25] Rajal VB, Cid AG, Ellenrieder G, Cuevas C. Production, partial purification and characterization of rhamnosidase from Penicilli- umulaiense. W J Microbiol Biotechnol. 2009, 25:1025_ 1033.http://dx.doi.org/10.1007/s11274-009-9979-4.

[26] Ribeiro MH. Naringinases: occurrences, characteristics and applications. Appl Microbiol Biotechnol. 2011,90:18831895http://dx.doi.org/10.1007/s00253-011-3176-8.

[27] Suzuki H. Hydrolysis of flavonoid glycosides by enzymes from Rhamnus daurica and other sources. Arch Biochem Biophys. 1962, 99:476-483.http://dx.doi.org/10.1016/0003-9861(62)90296-5.

[28] Thammawat K, Pongtanya P, Juntharasri V, Wongvithoonyaporn P. Isolation, preliminary enzyme characterization and optimization of culture parameters for production of naringinase isolated from Aspergillus niger BCC 25166. Kasetsart J. (Nat. Sci.). 2008,42:61-72.

[29] Thomas DW, Smythe CV, Labbee MD. Enzymatic hydrolysis of naringin, the bitter principle of grapefruit. Food Res. 1958, 23:591598.http://dx.doi.org/10.1111/j.1365-2621.1958.tb17609.x.

[30] Venâncio A, Rodrigues P, Soares C, Kozakiewicz Z, Paterson R.R.M, Lima N. Identification and characterization of Aspergillus flavus and aflatoxins. Communicating Current Research and Educational Topics and Trends in Applied Microbiology. 2007, 527-534.

[31] Waksman SA. A method for counting the number of fungi in the soil. Journal of bacteriology. 1922,7:339-341.

[32] Warcup JH. The Soil-Plate Method for Isolation of Fungi from Soil. Nature. 1950,166:117-118.http://dx.doi.org/10.1038/166117b0.

[33] Yadav V, Yadav S, Yadava S, Yadav KDS. $\alpha$-L-Rhamnosidase from Aspergillus flavus MTCC-9606 isolated from lemon fruit peel. International Journal of Food Science and Technology. 2011,46:350-357.http://dx.doi.org/10.1111/j.13652621.2010.02498.x.

[34] Yanai T, Sato M. Purification and characterization of a rhamnosidase from Pichia angusta X349. Biosci Biotechnol Biochem. 2000, 64:2179-2185.http://dx.doi.org/10.1271/bbb.64.2179. 